interests, who is able to perceive and satisfy the bibliographical needs of a large clientele. The needs of a really adequate information centre, for assembling scientific and technical information from India and elsewhere and for distributing such information, require consideration both from the point of view of organisation and material. The research aspect of information and intelligence work does not appear to have been recognized sufficiently in India; and the editor calls for a lead from the Indian Department of Scientific and Industrial Research towards the organisation of an efficient service on lines emphasized at the Royal Society Conference and already adopted not only by the Department of Scientific and Industrial Research in London but also in Australia, New Zealand and Canada, and by the National Researgh Council of the United States.

German Wool Industry

THE Wool Indystries-Research Association has recently prepared M.O.S. Overall Report No. 9 : The German Industry during the period 19391945" (p. P. A fondon: H.M. Stationery Office, $19481 s . \mathrm{bd})$. The report suggests that in respect of thenting, carding, spinning, weaving, dyeing, finis ling, shoddy and mungo manufacture, machinery design, operation and production there is little that the British industry can learn from its German counterpart. Much of the latter's woollen yarn industry was judged to be obsolete by American standards with, on the whole, low productivity, and, though allowance must be made for the quality of the raw material in use, the quality of work now being done was said to be poor by most of the investigators. Output was generally higher than with average Yorkshire setts ; but the standard of carding was lower. The modified Duhamel scouring process is economical in both alkali and soap, and merits careful examination. Much attention has been devoted by the Germans to by-product recovery, although there is nothing new in principle in the processes used. The exact efficiency of the German worsted industry is difficult to assess; but it would appear that while, compared with Britain, the German industry has the advantage of better build. ings, facilities and general amenities, German technicians have made no great mechanical or processing advances. Little advance in research was recorded in the war years, although some work on improving the sensitivity of wool to alkali, increasing the fastness of dyes, on moth-proofing, on low-temperature dyeing and the dyeing behaviour of the Palatine Fast dyes is noted. A bibliography of the reports and documents on which the report is based is appengled.

\section{Management Training at Staff College}

IN the paper "Tho-Staff College in Training for Management", I. N. F. Hall, principal of the Administrative s. Colff College, reviews his experimental work duf a th last two years in bringing the College ino opeption, and this paper has now been issued ify the British Institute of Management, together wit the introductory remarks of Sir Charles Renold and a report of the discussion, as the first report in the Winter Proceedings series of the Institute. Mr. Hall stresses that the task is to make a co-ordinated group out of individual specialists and to increase the capacity of those trained in administration and in different fields of technology to work together. The bulk of the work of each course is carried out by the discussion method, and this ensures that the basic principles of administration and their practical application will be examined. The study of biography has been introduced to provide opportunities for discussing the importance of personality and character in administration and to liberalize a concentrated practical course. While emphasizing the value of a well-balanced admixture of practical experience among the members of each session, Mr. Hall recog. nizes that the size of any mixed staff college must be small, both because of the importance of all members getting to know each other and because of the limits dictated by the group-discussion method used. Accordingly, great care should be exercised to avoid building up a privileged caste of those who have passed through the Staff College, from which there cannot at present be an annual output of more than about two hundred. As to the length of the course, Mr. Hall thinks it should remain at about three months or else be increased to a year; and for the present he thinks that three months represents a reasonable working compromise.

Fouad I University, Cairo: Faculty of Science

THE qual sert, 1946-47, of the faculty of science, Fored University of Cairo, gives a brief doscript of of the research activities, including par culans of papers published and some notes on researches in progress. In the Department of Pure Mathematics work is continuing on the distribution of cranial curves and on mortality tables, while in that of Applied Mathematics work is in progress on the unified field theory, the velocity potential of the fluid motion induced by the motion of a cylinder in an infinite mass of compressible fluid, and the effect of polarization on secondary scattered light. In the Department of Physics the subjects under investigation include electron polarization, viscosity of gases, electron diffraction by liquid films, the measurement of atmospheric turbulence, supersonic diffraction through slits and the viscosity of plastics. In the Department of Zoology the study of some biological and morphological aspects of lamellibranchs, the fauna of Egypt, the excretion of reptiles, and the embryology of scorpions is continuing, and a study has commenced of the anatomy, histology and physiology of the digestive system of some Egyptian Lacertilia. In the Department of Entomo. logy work continued on some of the Bombyliidæ of Egypt, and on the biology and ecology of various dung insects.

\section{The Country Journal

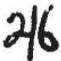

THE second number of the recently launched The Country Jour glontains a collection of articles which should gatisiy the varied tastes of those who live and w y 3 in the countryside and the unfortunate town thellers who wish to do so. There are articles for the farmer, the gardener, the botanist, the ofnithologist, the bee-keeper and the member of the women's institute; while in an admirable survey many of the recent books on natural history and rural subjects are classified for the convenience of several types of readers. In the present number of the journal two articles of absorbing interest are those by Frank Illingworth on the countryman's games and Trevor Holloway on curious country place-names. Particulars of the new journal may be obtained from the Worcester Press, Worcester. 